J. Dairy Sci. 98:5125-5132

http://dx.doi.org/10.3168/jds.2015-9404

(c) American Dairy Science Association ${ }^{\circledR}, 2015$.

\title{
Minor and potentially toxic trace elements in milk and blood serum of dairy donkeys
}

\author{
F. Fantuz, ${ }^{\star 1}$ S. Ferraro, $†$ L. Todini, ${ }^{*}$ R. Piloni, $†$ P. Mariani, ${ }^{*}$ E. Malissiova, $\ddagger$ and E. Salimei§ \\ *Dipartimento di Bioscienze e Medicina Veterinaria, and \\ †Dipartimento di Scienze e Tecnologie (sezione chimica), Università degli Studi di Camerino, 62032 Camerino, Italy \\ ‡Department of Food Technology, Technological Educational Institute of Thessaly, 43100 Karditsa, Greece \\ §Dipartimento di Agricoltura, Ambiente, Alimenti, Università degli Studi del Molise, 86100 Campobasso, Italy
}

\section{ABSTRACT}

The aim of this trial was to study the concentration of $\mathrm{Ti}, \mathrm{V}, \mathrm{As}, \mathrm{Rb}, \mathrm{Sr}, \mathrm{Mo}, \mathrm{Cd}, \mathrm{Cs}$, and $\mathrm{Pb}$ in donkey milk and blood serum. One hundred twelve individual milk and blood serum samples were collected from 16 lactating donkeys (Martina-Franca-derived population; 6 to 12 yr old; 3 to 7 parities; average live weight 205.4 $\mathrm{kg}$; 32 to $58 \mathrm{~d}$ after foaling at the beginning of the trial) during a 3-mo-long experiment. The samples were analyzed for the aforementioned elements by inductively coupled plasma-mass spectrometry. Feedstuff and drinking water were also analyzed for the investigated elements. Data were processed by ANOVA for repeated measures. Average milk concentrations $( \pm \mathrm{SD})$ of $\mathrm{Ti}, \mathrm{Rb}, \mathrm{Sr}, \mathrm{Mo}, \mathrm{Cs}$, and $\mathrm{Pb}$ were $77.3( \pm 7.7), 339.1$ $( \pm 82.1), 881.7( \pm 270.4), 4.5 \quad( \pm 1.6), 0.49( \pm 0.09)$, and $3.2( \pm 2.7) \mu \mathrm{g} / \mathrm{L}$, respectively. More than $80 \%$ of samples were below the limit of detection for V, As, and $\mathrm{Cd}$ in milk and for $\mathrm{Cd}$, and $\mathrm{Pb}$ in blood serum. The lower bound calculated for milk V, As, and $\mathrm{Cd}$ was $0.03 \mu \mathrm{g} / \mathrm{L}$ for the 3 elements, the upper bound was calculated at $0.23,0.10$, and $0.31 \mu \mathrm{g} / \mathrm{L}$ and the maximum value was observed at $0.54,0.15$, and 0.51 $\mu \mathrm{g} / \mathrm{L}$, respectively. The average milk concentrations of $\mathrm{Ti}, \mathrm{Rb}, \mathrm{Sr}, \mathrm{Mo}$, and $\mathrm{Cs}$ were $600,458,346,16$, and $294 \%$, respectively, than those of blood serum. Yet, Cs concentrations were in the same order of magnitude in milk and serum. Moderate to strong positive and significant correlation coefficients were observed between milk and blood serum concentrations for $\mathrm{Ti}, \mathrm{Rb}, \mathrm{Sr}$, and Cs. The effect of the stage of lactation was significant for all the investigated elements in milk and blood serum, but most of the elements showed only small changes or inconsistent trends, and only the concentrations of $\mathrm{Rb}$ and $\mathrm{Sr}$ showed decreasing trends both in milk and blood serum. The relationship between milk

Received January 30, 2015

Accepted April 26, 2015.

${ }^{1}$ Corresponding author: francesco.fantuz@unicam.it and blood serum element concentrations indicates that the mammary gland plays a role in determining the milk concentrations of Mo, Ti, Rb, Sr, Mo, and Cs. In the current experimental conditions, in agreement with the low levels in drinking water and feedstuff, donkey milk concentration of potentially toxic elements was very low and did not raise health concerns for human consumption.

Key words: dairy donkey, donkey milk, occasionally beneficial element, potentially toxic element

\section{INTRODUCTION}

Scientific interest in donkeys as a dairy species has increased because donkey milk can be considered a functional food for sensitive consumers such as infants and elderly people (Salimei, 2011). In particular, donkey milk can be considered a valid alternative to the available hypoallergenic formula for infants suffering from cow milk protein allergy, as reviewed by Salimei and Fantuz (2013). Knowledge of donkey milk production and composition has improved greatly in recent years: donkey milk shows similarities with human milk with regard to CP, lactose, and ash content, whereas the fat content is lower in donkey milk (Salimei and Fantuz, 2013). Detailed information on the nitrogen and fat fraction are now available (Salimei and Fantuz, 2013) but less attention has been paid to donkey milk macro mineral (Fantuz et al., 2009, 2012; Martini et al., 2014) and trace element content (Fantuz et al., 2013; Potorti et al., 2013; Bilandzic et al., 2014), despite the importance of dietary minerals in human nutrition. Milk contains several well-known nutritionally essential macro minerals and trace elements at different concentrations, but it also contains elements whose biological role, if any, is still not known, and other elements considered potentially toxic such as $\mathrm{As}, \mathrm{Cd}$, and $\mathrm{Pb}$ (Gaucheron, 2013). The mineral composition of milk depends on endogenous factors, such as species, stage of lactation, and health status of the mammary gland, and on exogenous factors such as diet. Literature data 
about minor trace elements in milk from dairy species are scarce and this topic is not well documented. The biological importance of minor elements such as $\mathrm{Ti}$, $\mathrm{V}, \mathrm{Rb}$, and Mo (but the same applies to As, Cd, and $\mathrm{Pb}$ ) is related to the fact that they can be grouped as occasionally beneficial elements at ultratrace level (estimated dietary requirements usually less than $1 \mathrm{mg} /$ $\mathrm{kg}$, and often less than $50 \mu \mathrm{g} / \mathrm{kg}$ of diet for laboratory animals; Nielsen, 1998; Suttle, 2010). The essentiality of Mo is now supported by substantial evidence and specific biochemical functions have been defined for this element (NRC, 2005). On the contrary, the occasional beneficial effect of $\mathrm{Ti}, \mathrm{V}, \mathrm{As}, \mathrm{Rb}, \mathrm{Cd}$, and $\mathrm{Pb}$ is based on the fact that, in experimental conditions, a suboptimal biological function due to dietary deprivation of a specific element may be prevented or reversed by an intake of physiological amounts of the element (Nielsen, 1998). Haenlein and Anke (2011) reviewed research focusing on deficiency effects of some elements in experimental ration fed to dairy goats. Based on tissue indicators and on reproductive efficiency, growth, milk production, health, and mortality of goats and their kids, the authors established deficiency and sufficiency dietary levels for $\mathrm{Ti}, \mathrm{V}, \mathrm{As}, \mathrm{Mo}$, and $\mathrm{Cd}$, among others elements. The majority of studies on $\mathrm{Sr}$ and $\mathrm{Cs}$ in milk dealt with radioactive isotopes, namely $\mathrm{Sr}^{90}$ and $\mathrm{Cs}^{137}$, as by-products of nuclear fission, and only little information is available on stable $\mathrm{Sr}$ and Cs. Strontium is not classified as an essential trace element but was shown to increase bone formation, and in humans, Srranelate is considered a potential pharmaceutical for the treatment of postmenopausal osteoporosis (NRC, 2005). The aim of this trial was to study the concentration of $\mathrm{Ti}, \mathrm{V}, \mathrm{As}, \mathrm{Rb}, \mathrm{Sr}, \mathrm{Mo}, \mathrm{Cd}$, Cs, and $\mathrm{Pb}$ in donkey milk and blood serum, also considering the effect of dietary essential trace element supplementation and stage of lactation.

\section{MATERIALS AND METHODS}

\section{Animals, Diet, and Sampling}

This on-field experiment was carried out at a private dairy farm producing donkey milk, located in a rural area of Reggio Emilia province, Italy $\left(44^{\circ} 38^{\prime} 9.24^{\prime \prime} \mathrm{N}\right.$, $\left.10^{\circ} 28^{\prime} 31.08^{\prime \prime} \mathrm{E}\right)$. The research protocol was in accordance with the European Commission guidelines (1986/609/EC) concerning the protection of animals used for experimental and other scientific purposes. Sixteen clinically healthy lactating donkeys (MartinaFranca-derived population; 6 to 12 yr old; 3 to 7 parities; average live weight $205.4 \mathrm{~kg}$; 32 to $58 \mathrm{~d}$ after foaling at the beginning of the trial) were used to provide individual milk and blood samples during a 3-mo period. As a part of a larger study focusing on essential trace elements in donkey milk, experimental animals were randomly divided into 2 homogeneous groups: control (CTL) and trace element (TE). Donkeys in each group had free access to meadow hay and fresh water. Donkeys were fed $2.5 \mathrm{~kg}$ of pelleted mixed feed (CP $14.3 \mathrm{~g} / 100 \mathrm{~g}$ of DM; NDF $29.4 \mathrm{~g} / 100 \mathrm{~g}$ of DM), divided in 2 meals per day. The mixed feed for the TE group had the same ingredients as CTL, but was supplemented with a commercial trace element premix providing $185 \mathrm{mg}$ of $\mathrm{Fe}$ (ferrous carbonate), $36 \mathrm{mg}$ of $\mathrm{Cu}$ (copper sulfate), $163 \mathrm{mg}$ of $\mathrm{Zn}$ (zinc oxide), 216 $\mathrm{mg}$ of $\mathrm{Mn}$ (manganese oxide), $3.20 \mathrm{mg}$ of I (calcium iodate), $2.78 \mathrm{mg}$ of Co (cobalt sulfate), and $0.67 \mathrm{mg}$ of Se (sodium selenite)/kg of mixed feed. Samples of feedstuff and drinking water were collected at d 0 and 42 from the beginning of the trial. Details on chemical composition of hay and mixed feeds together with details on housing of donkeys were described elsewhere (Fantuz et al., 2013). Individual and bulk milk samples were collected every 2 wk at $1100 \mathrm{~h}$ by mechanical milking as described by Salimei et al. (2004). Aliquots of milk samples were frozen and stored at $-20^{\circ} \mathrm{C}$ until analysis. All glassware and polyethylene tubes used for collection, storage, and analysis of samples were previously washed with 3\% nitric acid solution (Suprapur quality, Merck, Darmstadt, Germany). Blood samples were collected just after milking by jugular venipuncture in evacuated tubes (Venoject, Terumo Europe NV, Leuven, Belgium) without anticoagulant. Tubes were centrifuged and serum aliquots stored at $-20^{\circ} \mathrm{C}$ until analysis. The health of the mammary gland and the milk hygiene were checked during the trial by monitoring the SCC (Fossomatic 360, Foss, Hillerød, Denmark) and total bacteria (Bactoscan 8000, Foss) in fresh bulk milk samples.

\section{Feedstuff, Milk, and Blood Serum Analysis}

Ultrapure water obtained from a Millipore Milli-Q system (resistivity $18.2 \mathrm{M} \Omega \mathrm{cm}$ ) was used to prepare all solutions. Mineralization of thawed milk samples $(\mathrm{n}=112)$ was obtained as described by Fantuz et al. (2013). Briefly, $1 \mathrm{~mL}$ of sample was placed in a Teflon digestion vessel, followed by $3 \mathrm{~mL}$ of $\mathrm{HNO}_{3}(65 \%$, Suprapur quality, Merck). A microwave closed vessel system (Berghof Speedwave 4, Berghof, Eningen, Germany) was used for digestion. Digested solutions were transferred to a $10-\mathrm{mL}$ volumetric flask and diluted with ultrapure water. Digestion solution for feedstuff was made of $0.2 \mathrm{~g}$ of ground samples, $3.5 \mathrm{~mL}$ of $\mathrm{HNO}_{3}$ (65\%) (suprapur quality, Merck), and $3.5 \mathrm{ml}$ of $\mathrm{H}_{2} \mathrm{O}_{2}$ (30\%; Suprapur quality, Merck). Blood serum samples were diluted 1:20 with an $\mathrm{HNO}_{3}$ solution (1\%; Fantuz 
et al., 2013). The concentrations of Ti, V, As, Rb, Sr, $\mathrm{Mo}, \mathrm{Cd}, \mathrm{Cs}$, and $\mathrm{Pb}$ in the acid digested solution or in acidified $\left(\mathrm{HNO}_{3} 1 \%\right)$ blood serum and drinking water were measured by inductively coupled plasma-mass spectrometry (Agilent Technologies, $7500 \mathrm{cx}$ series) as previously described (Fantuz et al., 2013). The limits of detection $(\mathbf{L O D})$, expressed as concentration $(\mu \mathrm{g} / \mathrm{L})$ of the elements in the digested solution and diluted blood serum, were calculated as 3 times the standard deviation of 10 repeated determinations of the blank (Table 1 ). When less than $20 \%$ of the samples were below the LOD, results below the LOD were replaced by LOD $/ 2$. When more than $80 \%$ of the samples were below the LOD, only lower bound (results $<$ LOD replaced by 0 ) and upper bound (results < LOD replaced by LOD) were calculated (EFSA, 2010). Analysis of certified reference material, nonfat milk powder NIST SRM 1549 (National Institute of Standards and Technology, Gaithersburg, MD) and Seronorm Trace Elements Serum L-2 (Sero As, Billingstad, Norway) were regularly performed, within each batch analysis, to validate the accuracy of the analytical procedure. Certified values were available for milk $\mathrm{Cd}$ and $\mathrm{Pb}$ and only information or approximate values were available for $\mathrm{As}, \mathrm{Rb}$, and Mo in NIST SRM 1549, and for other investigated elements in Seronorm Trace Elements Serum L-2. Neither certified nor information values were available for $\mathrm{Ti}$, V, Sr, and Cs in NIST SRM 1549. For the purpose of the present research, analytical results agreed well with certified or approximate values in reference materials (Table 1).

\section{Statistical Analysis}

Descriptive statistics were calculated using SPSS 12.0 (SPSS Inc., Chicago, IL). As checked by KolmogorovSmirnoff test, milk Ti and $\mathrm{Sr}$ and serum $\mathrm{Ti}$ and $\mathrm{As}$ concentrations had normal distribution. Data on milk $\mathrm{Rb}$ and Mo, and on serum Sr and Mo were logarithmic transformed, whereas data on milk $\mathrm{Pb}$ and $\mathrm{Cs}$, and on serum V, Rb, and Cs were square root transformed before statistical analysis. To evaluate the effects of stage of lactation (within-subject factor) and dietary treatment (between-subject factors), data were processed by ANOVA for repeated measures (SPSS Inc.). Data from the first sampling time were used as a covariate when significant. In the case of significant effects $(P<0.05)$, differences between means were analyzed by LSD. Association between variables was examined by calculating simple linear correlations. Significant correlations were declared strong $(\mathrm{r}>0.7)$, moderate ( $\mathrm{r}$ from 0.3 to $0.7)$, or weak $(\mathrm{r}<0.3)$.

\section{RESULTS}

Milk hygiene and health of the mammary gland were good as demonstrated by the low somatic cell count $(7,300$ cells $/ \mathrm{mL})$ and total bacteria $(3,400 \mathrm{cfu} / \mathrm{mL})$ in bulk milk. The concentrations of Ti, V, As, Rb, Sr, Mo, $\mathrm{Cd}, \mathrm{Cs}$, and $\mathrm{Pb}$ in drinking water and feedstuff are reported in Table 2. Descriptive statistics on investigated elements in donkey milk and blood serum are summarized in Tables 3 and 4, respectively. The percentage of milk samples below the LOD was $89.2 \%$ for V, $80.3 \%$ for As, and $92.8 \%$ for $\mathrm{Cd}$. The lower bound calculated for milk V, As, and Cd was the same, $0.03 \mu \mathrm{g} / \mathrm{L}$, for the 3 elements; the upper bound was calculated at 0.23 , 0.10 , and $0.31 \mu \mathrm{g} / \mathrm{L}$; and the maximum value was observed at $0.54,0.15$, and $0.51 \mu \mathrm{g} / \mathrm{L}$, respectively. The percentage of serum samples below the LOD was $88.4 \%$ for $\mathrm{Cd}$ and $81.2 \%$ for $\mathrm{Pb}$. The lower bound calculated for serum $\mathrm{Cd}$ and $\mathrm{Pb}$ was 0.04 and 0.16 , and the upper bound was 0.13 and $0.56 \mu \mathrm{g} / \mathrm{L}$, respectively. The maximum serum $\mathrm{Cd}$ concentration was observed at

Table 1. Trace element concentration $( \pm \mathrm{SD})$ in certified reference materials (nonfat milk powder NIST 1549, National Institute of Standards and Technology, Gaithersburg, MD; and blood serum Seronorm Trace Elements Serum L-2, Sero As, Billingstad, Norway) and limits of detection (LOD)

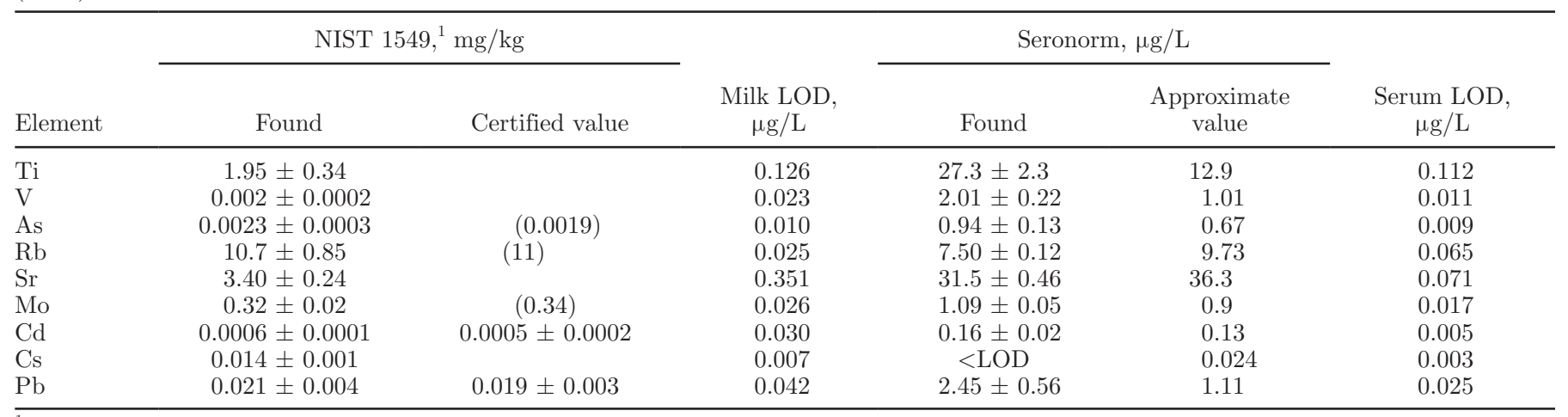

${ }^{1}$ NIST 1549 information values in parentheses. 
Table 2. Concentration of minor and potentially toxic elements in drinking water and in feedstuff

\begin{tabular}{lcccc}
\hline & & & \multicolumn{2}{c}{ Mixed feed, ${ }^{1} \mathrm{mg} / \mathrm{kg}$ of DM } \\
\cline { 3 - 5 } Element & $\begin{array}{c}\text { Water, } \\
\mu \mathrm{g} / \mathrm{L}\end{array}$ & $\mathrm{M}$ & $\mathrm{CTL}$ & $\mathrm{TE}$ \\
\hline $\mathrm{mi} / \mathrm{kg}$ of DM & 3.1 & 11.3 & 10.5 \\
$\mathrm{~V}$ & 0.03 & 0.27 & 1.4 & 1.5 \\
$\mathrm{As}$ & 0.11 & 0.04 & 0.14 & 0.16 \\
$\mathrm{Rb}$ & 0.11 & 10.4 & 8.8 & 8.8 \\
$\mathrm{Sr}$ & 0.58 & 60.3 & 32.5 & 1.4 \\
$\mathrm{Mo}$ & 371.3 & 1.4 & 0.09 & 0.10 \\
$\mathrm{Cd}$ & 0.58 & 0.07 & 0.16 & 0.14 \\
$\mathrm{Cs}$ & 0.03 & 0.03 & 0.42 & 0.44 \\
$\mathrm{~Pb}$ & 0.005 & 0.10 & & \\
\hline
\end{tabular}

${ }^{1}$ CTL mixed feed was composed of barley, dehydrated alfalfa $(15 \% \mathrm{CP})$, wheat, wheat bran, pea, calcium carbonate, bicalcium phosphate, sodium chloride. In TE mixed feed, $0.25 \%$ trace element premix was included, providing $163 \mathrm{mg}$ of $\mathrm{Zn}$ (zinc oxide), $185 \mathrm{mg}$ of $\mathrm{Fe}$ (ferrous carbonate), $36 \mathrm{mg}$ of $\mathrm{Cu}$ (copper sulfate), $216 \mathrm{mg}$ of $\mathrm{Mn}$ (manganese oxide), $0.67 \mathrm{mg}$ of Se (sodium selenite), $2.78 \mathrm{mg}$ of Co (cobalt sulfate), and $3.20 \mathrm{mg}$ of I (calcium iodate) $/ \mathrm{kg}$.

$0.78 \mu \mathrm{g} / \mathrm{L}$ and that of $\mathrm{Pb}$ at $1.47 \mu \mathrm{g} / \mathrm{L}$. The transfer of the analyzed elements from blood into milk appeared to occur at a different rate for the different elements: the average milk concentrations of $\mathrm{Ti}, \mathrm{Rb}, \mathrm{Sr}, \mathrm{Mo}$, and Cs were $600,458,346,16$, and $294 \%$, respectively, than those of blood serum. Yet, Cs concentrations were in the same order of magnitude in milk and serum. Although precise relationships between milk and serum concentrations were not established for $\mathrm{V}, \mathrm{As}, \mathrm{Cd}$, and $\mathrm{Pb}$, it can be argued that $\mathrm{Pb}$ concentration in donkey milk was higher than that in serum. Moderate to strong correlation coefficients were observed between milk and blood serum concentrations for $\mathrm{Ti}(\mathrm{r}=0.34 ; P=0.01)$, $\mathrm{Rb}(\mathrm{r}=0.84 ; P=0.001), \operatorname{Sr}(\mathrm{r}=0.75 ; P=0.001)$, and Cs $(\mathrm{r}=0.52 ; P=0.001)$. The dietary supplementation with $\mathrm{Zn}, \mathrm{Fe}, \mathrm{Cu}, \mathrm{Mn}, \mathrm{Se}, \mathrm{Co}$, and I did not significantly affect the concentration of the investigated elements in milk and blood serum (results not shown). The effect of stage of lactation was significant for all the investigated elements in milk (Table 5) and blood serum (Table 6). The concentrations of milk Ti, Mo, and Cs, and of serum V, As, and Cs showed small changes and the trends of milk $\mathrm{Pb}$ and serum $\mathrm{Ti}, \mathrm{Mo}$, and $\mathrm{Cs}$ did not show consistency. The concentrations of $\mathrm{Rb}$ and $\mathrm{Sr}$ in milk and blood serum were lower during the second part of the trial. The effect of treatment $\times$ stage of lactation interaction was not significant for all variables.

\section{DISCUSSION}

The concentrations of the analyzed elements in water were within the range reported for tap water in Italy and did not give concerns about contamination with potentially toxic elements (Dinelli et al., 2012). The difference between analyzed elements in CTL and TE mixed feed was small except for Mo whose concentration was about $70 \%$ higher in TE mixed feed compared with CTL, likely because of Mo residues associated with the trace element premix included in the mixed feed. Current results are substantially consistent with the available data on $\mathrm{Ti}, \mathrm{V}, \mathrm{Rb}, \mathrm{Sr}$, and Mo in feedstuff (NRC, 2005; Suttle, 2010; Van Paemel et al., 2010). The concentrations of $\mathrm{As}, \mathrm{Cd}$, and $\mathrm{Pb}$ in feedstuff did not exceed the limits indicated by the European rules for hay and complementary feeds with $88 \% \mathrm{DM}$ and are consistent with data available for noncontaminated feedstuff (Patra et al., 2008; Van Paemel et al., 2010). Assuming the DMI at $3.2 \%$ BW (Salimei, 2011) and considering the known amount of mixed feeds fed to the donkeys, the daily intake of hay was estimated at

Table 3. Descriptive statistics for selected trace elements $(\mu \mathrm{g} / \mathrm{L})$ in donkey milk

\begin{tabular}{|c|c|c|c|c|c|c|}
\hline Item & $\mathrm{Ti}$ & $\mathrm{Rb}$ & $\mathrm{Sr}$ & Mo & Cs & $\mathrm{Pb}$ \\
\hline Mean & 77.3 & 339.1 & 881.7 & 4.5 & 0.49 & 3.2 \\
\hline Median & 76.1 & 320.9 & 829.9 & 3.9 & 0.47 & 2.6 \\
\hline $\mathrm{SD}$ & 7.7 & 82.1 & 270.4 & 1.6 & 0.09 & 2.7 \\
\hline $95 \% \mathrm{CI}^{1}$ & $75.7-78.8$ & $322.7-356.2$ & $826.6-936.8$ & $4.05-4.72$ & $0.47-0.51$ & $2.8-4.1$ \\
\hline Minimum & 65.3 & 156.1 & 307.7 & 1.8 & 0.34 & $<0.42$ \\
\hline Maximum & 104.5 & 502.1 & $1,728.7$ & 12.4 & 0.78 & 12.5 \\
\hline 1st quartile & 71.3 & 268.1 & 680.4 & 3.3 & 0.42 & 1.3 \\
\hline 3rd quartile & 81.5 & 408.2 & $1,082.7$ & 5.0 & 0.56 & 4.2 \\
\hline
\end{tabular}

${ }^{1}$ Confidence interval for the mean. 
Table 4. Descriptive statistics for selected trace elements $(\mu \mathrm{g} / \mathrm{L})$ in blood serum of lactating donkeys

\begin{tabular}{lcllcccc}
\hline Item & $\mathrm{Ti}$ & \multicolumn{1}{c}{$\mathrm{V}$} & $\mathrm{Rb}$ & $\mathrm{Sr}$ & $\mathrm{As}$ & $\mathrm{Mo}$ \\
\hline Mean & 12.4 & 1.0 & 74.1 & 254.8 & 0.49 & 28.5 \\
Median & 11.8 & 0.88 & 74.9 & 247.5 & 0.47 & 25.5 \\
SD & 3.7 & 0.38 & 15.2 & 56.0 & 0.12 & 13.8 \\
95\% CI & $11.6-13.2$ & $0.90-1.10$ & $70.9-77.2$ & $243.3-251.9$ & $0.47-0.52$ & $25.5-31.4$ & 0.17 \\
Minimum & 5.9 & 0.40 & 48.1 & 160.2 & 0.26 & 0.16 \\
Maximum & 23.9 & 2.0 & 67.2 & 416.7 & 0.82 & 79.6 & 0.09 \\
1st quartile & 9.9 & 0.69 & 60.6 & 207.3 & 0.40 & 0.49 \\
3rd quartile & 13.8 & 1.4 & 88.0 & 292.5 & 0.56 & 35.6 & 0.13 \\
\hline
\end{tabular}

${ }^{1}$ Confidence interval for the mean.

$4.62 \mathrm{~kg}$ of DM. Consequently, the calculated concentrations of the investigated elements in the CTL diet $(\mathrm{mg} / \mathrm{kg}$ of DM) were as follows: $5.8 \mathrm{Ti}, 0.65 \mathrm{~V}, 0.07$ As, $9.9 \mathrm{Rb}, 50.7 \mathrm{Sr}, 1.3 \mathrm{Mo}, 0.08 \mathrm{Cd}, 0.07 \mathrm{Cs}$, and 0.2 $\mathrm{Pb}$. These concentrations are lower than the maximum tolerable levels of $\mathrm{V}, \mathrm{As}, \mathrm{Sr}, \mathrm{Mo}, \mathrm{Cd}$, and $\mathrm{Pb}$ in diets for horses (NRC, 2005). The dietary Mo concentration in the CTL and TE group did not raise concerns for interactions with $\mathrm{S}$ and $\mathrm{Cu}$. Interactions between $\mathrm{Mo}$, $\mathrm{S}$, and $\mathrm{Cu}$ are of great importance in ruminant nutrition because dietary Mo and $\mathrm{S}$ concentrations as low as $5 \mathrm{mg} / \mathrm{kg}$ of $\mathrm{DM}$ and $0.3 \%$, respectively, can decrease $\mathrm{Cu}$ availability and increase the risk of $\mathrm{Cu}$ deficiency (NRC, 2005). On the contrary, although the maximum tolerable level of dietary Mo for horses (derived from interspecies extrapolation) was established at the same level as that of cow and sheep ( $5 \mathrm{mg} / \mathrm{kg}$ of DM), interactions between $\mathrm{Cu}$ and $\mathrm{Mo}$ are reported to be minimal in nonruminants (NRC, 2005), and in horses, exposure to Mo does not impair $\mathrm{Cu}$ metabolism or raise $\mathrm{Cu}$ requirements (Suttle, 2010). In the study by Rieker et al. (2000), a dietary Mo concentration of $20 \mathrm{mg} / \mathrm{kg}$ of DM did not appear to interfere with $\mathrm{Cu}$ utilization in geldings. It should also be noted that dietary concentration of $\mathrm{Cu}$ in $\mathrm{TE}$ group was 2.6 times higher than that in CTL group (Fantuz et al., 2013).

Among the investigated elements, on the basis of available knowledge, only Mo can be considered essential in nutrition. Bacteria require Mo for nitrogen fixation and for reduction of nitrate to nitrite and Mo has been identified as a component of 3 mammalian enzymes: xanthine oxidase, aldehyde oxidase, and sulfite oxidase (NRC, 2005). No data are available on Mo in donkey milk, but the observed average concentration was similar $(3.5 \mu \mathrm{g} / \mathrm{L}$; Björklund et al., 2012) or lower $(17 \mu \mathrm{g} / \mathrm{L})$ than published values for human milk (Anderson, 1992) and lower than horse $(16 \mu \mathrm{g} / \mathrm{L})$ and cow milk (22 to $45 \mu \mathrm{g} / \mathrm{L}$; Anderson, 1992; Rey-Crespo et al., 2013). Observed Mo concentration is consistent with values reported for goat milk (1.9 to $7.1 \mu \mathrm{g} / \mathrm{L}$ ) (Trancoso et al., 2009). The concentration of Mo in goat milk can be increased when goats are fed control $(0.5 \mathrm{mg} / \mathrm{kg}$ of $\mathrm{DM})$ as opposed to Mo-deficient diet $(0.02 \mathrm{mg} / \mathrm{kg}$ DM; Haenlein and Anke, 2011). It is reported that Mo requirements in livestock are easily met feeding practical diets, although Mo requirements are not well established. A dietary requirement of $0.1 \mathrm{mg}$ $\mathrm{Mo} / \mathrm{kg}$ of DM was indicated for beef cattle and dietary level of $0.5 \mathrm{mg} / \mathrm{kg}$ of $\mathrm{DM}$ for sheep and from 0.1 to $1 \mathrm{mg} / \mathrm{kg}$ of DM for goats were indicated as general recommendations (Van Paemel et al., 2010). Therefore, it can be assumed that in the current study Mo concentration in the CTL diet met or exceeded dietary Mo requirements for donkeys. The fact that the higher dietary Mo in TE group did not increase the milk and the blood serum Mo concentration is in agreement with findings by Fantuz et al. (2013), who observed that the concentrations of some essential trace elements in donkey milk are not related to dietary intake, at least when dietary requirements are fulfilled. Moreover, the

Table 5. Selected trace elements $(\mu \mathrm{g} / \mathrm{L})$ in donkey milk during lactation

\begin{tabular}{|c|c|c|c|c|c|c|c|}
\hline \multirow[b]{2}{*}{ Item } & \multicolumn{6}{|c|}{ Days of lactation } & \multirow[b]{2}{*}{ SEM } \\
\hline & $46-72$ & $60-86$ & $74-100$ & $88-114$ & $102-128$ & $116-142$ & \\
\hline $\mathrm{Ti}$ & $72.6^{\mathrm{b}}$ & $73.3^{\mathrm{b}}$ & $74.1^{\mathrm{b}}$ & $87.0^{\mathrm{a}}$ & $83.1^{\mathrm{a}}$ & $74.1^{\mathrm{b}}$ & 1.86 \\
\hline $\mathrm{Sr}$ & $1,178.0^{\mathrm{a}}$ & $1,185.1^{\mathrm{a}}$ & $772.9^{\mathrm{b}}$ & $700.1^{\mathrm{b}}$ & $689.6^{\mathrm{b}}$ & $767.9^{\mathrm{b}}$ & 30.9 \\
\hline Мо & $4.5^{\mathrm{a}}$ & $4.7^{\mathrm{a}}$ & $4.8^{\mathrm{a}}$ & $4.7^{\mathrm{a}}$ & $4.3^{\mathrm{a}}$ & $3.4^{\mathrm{b}}$ & 0.35 \\
\hline Cs & $0.62^{\mathrm{a}}$ & $0.61^{\mathrm{a}}$ & $0.46^{\mathrm{b}}$ & $0.39^{c}$ & $0.46^{\mathrm{b}}$ & $0.55^{\mathrm{b}}$ & 0.02 \\
\hline
\end{tabular}

${ }^{\mathrm{a}-\mathrm{d}}$ Means within a row with different superscripts differ $(P<0.05)$. 
Table 6. Selected trace elements $(\mu \mathrm{g} / \mathrm{L})$ in blood serum of lactating donkeys during lactation

\begin{tabular}{|c|c|c|c|c|c|c|c|}
\hline Item & \multicolumn{6}{|c|}{ Days of lactation } & SEM \\
\hline $\mathrm{Ti}$ & $15.0^{\mathrm{a}}$ & $15.3^{\mathrm{a}}$ & $12.8^{\mathrm{b}}$ & $9.16^{\mathrm{d}}$ & $11.4^{\mathrm{bc}}$ & $11.1^{\mathrm{c}}$ & 0.65 \\
\hline As & $0.54^{\mathrm{ab}}$ & $0.61^{\mathrm{a}}$ & $0.42^{\mathrm{d}}$ & $0.45^{\mathrm{cd}}$ & $0.40^{\mathrm{d}}$ & $0.50^{\mathrm{bc}}$ & 0.03 \\
\hline $\mathrm{Rb}$ & $90.8^{\mathrm{a}}$ & $92.8^{\mathrm{a}}$ & $80.5^{\mathrm{b}}$ & $57.5^{\mathrm{d}}$ & $62.9^{\mathrm{c}}$ & $61.6^{\mathrm{c}}$ & 1.32 \\
\hline $\mathrm{Sr}$ & $301.7^{\mathrm{b}}$ & $334.3^{\mathrm{a}}$ & $212.2^{\mathrm{d}}$ & $246.2^{\mathrm{c}}$ & $201.8^{\mathrm{d}}$ & $257.0^{\mathrm{c}}$ & 6.51 \\
\hline
\end{tabular}

${ }^{\mathrm{a}-\mathrm{d}}$ Means within a row with different superscripts differ $(P<0.05)$.

difference in Mo concentration between CTL and TE diet could have been too low (1.3 vs. $1.5 \mathrm{mg} / \mathrm{kg}$ of DM) to affect Mo concentrations in milk and blood serum.

Compared with data from the current experiment, cow milk contains a similar concentration of Ti (54 to $111 \mu \mathrm{g} / \mathrm{L}$; Anderson, 1992; Dobrzanski et al., 2005), and higher V $(6.3 \mu \mathrm{g} / \mathrm{L})$ and Cs levels $(9.3 \mu \mathrm{g} / \mathrm{L}$; Khan et al., 2014). Low $\mathrm{V}$ concentration $(0.07 \mu \mathrm{g} / \mathrm{L})$ was observed in human milk, whereas the Cs concentration was higher (1.1 to $11 \mu \mathrm{g} / \mathrm{L}$ ) compared with current results (Rossipal and Krachler, 1998; Björklund et al., 2012). Average Ti concentration in human and horse milk was reported at 25 and $145 \mu \mathrm{g} / \mathrm{L}$, respectively (Anderson, 1992). Based on findings by Fantuz et al. (2013) and Bilandzic et al. (2014), Sr and Rb in donkey milk represent, respectively, the second and third highest concentrations among trace elements after that of Zn. Donkey milk Sr concentration was higher than that observed in cow (417 to $698 \mu \mathrm{g} / \mathrm{L}$ ) and horse milk (442 $\mu \mathrm{g} / \mathrm{L}$ ), whereas $\mathrm{Rb}$ concentration was higher in cow milk (2,088 to 2,330 $\mu \mathrm{g} / \mathrm{L}$; Anderson, 1992; Khan et al., 2014). Dobrzanski et al. (2005) observed Rb in cow milk ranging from 290 to $840 \mu \mathrm{g} / \mathrm{L}$ depending on the area of milk collection. Human milk contains lower $\mathrm{Sr}$ (33 to $60 \mu \mathrm{g} / \mathrm{L})$ and higher Rb concentration $(714 \mu \mathrm{g} / \mathrm{L}$; Anderson, 1992; Björklund et al., 2012) than donkey milk. In the current experiment $\mathrm{Sr}$ was systematically dominant over $\mathrm{Rb}$ concentration, whereas in the mentioned studies $\mathrm{Rb}$ was higher than Sr. Data on $\mathrm{Rb}$ and Sr in donkey milk need to be confirmed with other diets and in different geological areas. Indeed, donkey milk samples from another dairy farm located in central Italy contained 897 and $497 \mu \mathrm{g} / \mathrm{L}$, respectively, for $\mathrm{Rb}$ and $\mathrm{Sr}$ (F. Fantuz, 2015, unpublished data).

The only study available in literature for potentially toxic elements in donkey milk (Potorti et al., 2013) reported higher concentrations for As (ranging from 13.9 to $142.5 \mu \mathrm{g} / \mathrm{L}), \mathrm{Cd}(1.1$ to $20.4 \mu \mathrm{g} / \mathrm{L})$, and $\mathrm{Pb}$ $(2.4$ to $59.8 \mu \mathrm{g} / \mathrm{L})$ than those observed in the current experiment. However, comparison with $\mathrm{As}, \mathrm{Cd}$, and $\mathrm{Pb}$ levels in feedstuff described by Potorti et al. (2013) is difficult because of the composition, including grass silage, of the different diets and lack of information on DM content of diets. More data are available for potentially toxic elements in milk from human and other species. Similar to the current study, milk As and $\mathrm{Cd}$ concentrations below the LOD or averaging less than 1 $\mu \mathrm{g} / \mathrm{L}$ were observed in human (Leotsinidis et al., 2005; Björklund et al., 2012; Chao et al., 2014), cow (Rahimi, 2013; Rey-Crespo et al., 2013), and goat milk (Trancoso et al., 2009). Low average milk $\mathrm{Pb}$ concentration $(<10 \mu \mathrm{g} / \mathrm{L})$ was also observed in human (Leotsinidis et al., 2005; Björklund et al., 2012), cow (Rey-Crespo et al., 2013; Khan et al., 2014), and goat milk (Trancoso et al., 2009; Rahimi, 2013). However, variable results on potentially toxic elements were reported in literature for cow milk (Dobrzanski et al., 2005; Bilandzic et al., 2011). For instance, high concentrations of $\mathrm{Cd}$ and $\mathrm{Pb}$ were measured in milk samples collected from cows reared around industrial units (Swarup et al., 2005; Patra et al., 2008). It should be noted that only few studies on potentially toxic trace elements in milk from dairy species report data on element concentration in feedstuff and water. Although a direct relationship between milk concentration and dietary intake of potentially toxic elements was not yet established unambiguously, the current low levels of potentially toxic elements in donkey milk agree with the low levels in feedstuff and drinking water. Furthermore, Ca supplementation to the diet of experimental donkeys may have limited $\mathrm{Cd}$ and $\mathrm{Pb}$ absorption (NRC, 2005; Suttle, 2010).

To the authors' knowledge, blood serum references are not available for the investigated trace elements in dairy animals nor are data available about the relationship between minor trace elements in milk and blood serum, and only little information is available for humans. Current data on donkeys are partially in agreement with findings by Krachler et al. (1999) who reported higher concentrations of $\mathrm{Rb}, \mathrm{Sr}, \mathrm{Cs}$, and $\mathrm{Pb}$ in human colostrum compared with maternal blood serum, but opposite to this study, Krachler et al. (1999) reported higher Mo concentration in colostrum than 
in blood serum. Previously, higher Zn, Mn, and I, and lower $\mathrm{Fe}, \mathrm{Cu}$, Se, and $\mathrm{Co}$ compared with respective serum levels were observed in donkey milk (Fantuz et al., 2013). The presence of mechanisms able to uptake elements into the mammary gland with subsequent secretion into milk was described for essential elements such as $\mathrm{Ca}, \mathrm{P}, \mathrm{K}$, and $\mathrm{Zn}$, and the homeostatic control of mammary gland on milk $\mathrm{Fe}$ and $\mathrm{Cu}$ was also reported (Shennan and Peaker, 2000; Lonnerdal, 2007). Current observations support the hypothesis that the mammary gland regulates the milk content of some minor trace elements, promoting the transfer of $\mathrm{Ti}, \mathrm{Rb}, \mathrm{Sr}$, and $\mathrm{Cs}$ from blood into milk and inhibiting the transfer of Mo. On the other hand, considering the significant and positive correlations observed between milk and serum Ti, $\mathrm{Rb}, \mathrm{Sr}$, and Cs concentrations, passive transfer can also be hypothesized for such elements. On the contrary, the absence of relationship between Mo in milk and blood serum suggest that Mo concentration in donkey milk is independent from maternal Mo status and no passive transfer occurred across the mammary epithelium. Positive correlation coefficient between $\mathrm{Sr}$ concentration in human colostrum and blood serum was previously reported (Krachler et al., 1999). Nevertheless, the relationship between trace element in blood and milk likely depends also on the actual blood level of a specific elements: Swarup et al. (2005) observed significant correlation between cow milk and blood $\mathrm{Pb}$ only with blood $\mathrm{Pb}$ concentration above $0.20 \mathrm{mg} / \mathrm{L}$.

Although the effect of stage of lactation was significant for all elements, only $\mathrm{Rb}$ and $\mathrm{Sr}$ concentrations showed decreasing trends in milk and blood serum. It should be noted that $\mathrm{Rb}$ and $\mathrm{Sr}$ show chemical properties similar to $\mathrm{K}$ and $\mathrm{Ca}$, respectively, sharing regulating and transport mechanisms (NRC, 2005). In this regard, the concentration of $\mathrm{Ca}$ in donkey milk, as well as those of $\mathrm{P}, \mathrm{Mg}, \mathrm{Cu}$, and $\mathrm{Se}$, declines as lactation progresses, but that of $\mathrm{K}$ does not follow a consistent trend (Fantuz et al., 2012, 2013). The concentrations of others investigated elements showed only small, albeit significant, changes or inconsistent trends. A decline of $\mathrm{Cd}, \mathrm{As}$, and $\mathrm{Pb}$ was observed in human milk until 2 mo from parturition (Chao et al., 2014). Rossipal and Krachler (1998) reported higher concentrations of $\mathrm{Pb}$ in human colostrum or transitory milk compared with mature milk, whereas the concentrations of Cs and $\mathrm{Sr}$ remain unchanged during the course of lactation.

\section{CONCLUSIONS}

The current study provided novel information on minor trace elements and added new data on potentially toxic elements in donkey milk. When compared with published data on human milk, donkey milk generally shows similar or lower $\mathrm{V}$ and Mo concentrations, higher $\mathrm{Ti}$ and $\mathrm{Sr}$, and lower $\mathrm{Cs}$ and $\mathrm{Rb}$. Compared with cow milk, donkey milk contains similar or lower $\mathrm{Ti}$, lower $\mathrm{V}, \mathrm{Mo}, \mathrm{Rb}$, and Cs, and higher Sr. The current study also provided first data on minor and potentially toxic elements in blood serum of lactating donkeys. Donkey milk shows a lower concentration of Mo and higher concentrations of $\mathrm{Ti}, \mathrm{Rb}, \mathrm{Sr}$, and Cs compared with their respective blood serum concentrations, suggesting that the mammary gland plays a role in determining the milk concentrations of such elements. In the current experimental conditions, in agreement with the low levels in drinking water and feedstuff, donkey milk concentration of potentially toxic elements was very low and did not raise health concerns for human consumption.

\section{ACKNOWLEDGMENTS}

Funds by F. Fantuz, S. Ferraro, and L. Todini (Università di Camerino) were used for this study. The authors acknowledge the valuable collaboration of $\mathrm{D}$. Borghi, G. Borghi, and T. Faietti (Azienda Agricola Montebaducco, Salvarano di Quattro Castella, Reggio Emilia, Italy), and of C. Merlo (Azienda Agricola Ciucolandia, Capestrano, L'Aquila, Italy). The authors are also grateful to C. Neiertz for language revision, and to V. Brunetti, G. Lebboroni (all of Università di Camerino), and A. El Jeddad (Azienda Agricola Montebaducco) for technical assistance.

\section{REFERENCES}

Anderson, R. R. 1992. Comparison of trace elements in milk of four species. J. Dairy Sci. 75:3050-3055.

Bilandzic, N., M. Dokic, M. Sedak, B. Solomun, I. Varenina, Z. Knezevic, and M. Benic. 2011. Trace element levels in raw milk from northern and southern regions of Croatia. Food Chem. 127:63-66.

Bilandzic, N., M. Sedak, M. Dokic, B. Solomun Kolanovic, I. Varenina, D. Bozic, and A. Koncurat. 2014. Differences of the essential mineral element levels in the milk of Croatian Coldblood horse and Littoral-Dinaric donkey. Mljekarstvo. 64:12-18.

Björklund, K. L., M. Vahter, B. Palm, M. Grandér, S. Lignell, and M. Berglund. 2012. Metals and trace element concentrations in breast milk of first time healthy mothers: A biological monitoring study. Environ. Health 11:92.

Chao, H. H., C. H. Guo, C. B. Huang, P. C. Chen, H. C. Li, D. Y. Hsiung, and Y. K. Chou. 2014. Arsenic, cadmium, lead, and aluminium concentrations in human milk at early stages of lactation. Pediatr. Neonatol. 55:127-134.

Dinelli, A., A. Lima, S. Albanese, M. Birke, D. Cicchella, L. Giaccio, P. Valera, and B. De Vivo. 2012. Comparative study between bottled mineral and tap water in Italy. J. Geochem. Explor. 112:368-389.

Dobrzanski, Z., R. Kolacz, H. Górecka, K. Chojnacka, and A. Bartkowiak. 2005. The content of microelements and trace elements in raw milk from cows in the Silesian region. Pol. J. Environ. Stud. 14:685-689.

EFSA (European Food Safety Authority). 2010. Management of leftcensored data in dietary exposure assessment of chemical substances. EFSA J. 8:1557.

Fantuz, F., S. Ferraro, L. Todini, P. Mariani, R. Piloni, and E. Salimei. 2013. Essential trace elements in milk and blood serum of lactating 
donkeys as affected by lactation stage and dietary supplementation with trace elements. Animal 7:1893-1899.

Fantuz, F., S. Ferraro, L. Todini, R. Piloni, P. Mariani, and E. Salimei. 2012. Donkey milk concentration of calcium, phosphorus, potassium, sodium and magnesium. Int. Dairy J. 24:143-145.

Fantuz, F., C. Maglieri, G. Lebboroni, and E. Salimei. 2009. Ca, Mg, $\mathrm{Zn}, \mathrm{Fe}, \mathrm{Cu}$ and $\mathrm{Mn}$ content of ass's milk. Ital. J. Anim. Sci. 8(Suppl. 2):703-705.

Gaucheron, F. 2013. Milk minerals, trace elements and macroelements. Pages 172-199 in Milk and Dairy Product in Human Nutrition: Production, Composition and Health. Y. W. Park and G. F. W. Haenlein, ed. John Wiley \& Sons, Oxford, UK.

Haenlein, G. F. W., and M. Anke. 2011. Mineral and trace element research in goats: A review. Small Rumin. Res. 95:2-19.

Khan, N., I. S. Jeong, I. M. Hwang, J. S. Kim, S. H. Choi, E. Y. Nho, J. Y. Choi, K. S. Park, and K. S. Kim. 2014. Analysis of minor and trace elements in milk and yogurts by inductively coupled plasmamass spectrometry (ICP-MS). Food Chem. 147:220-224.

Krachler, M., E. Rossipal, and D. Micetic-Turk. 1999. Trace element transfer from the mother to the newborn-Investigations on triplets of colostrum, maternal and umbilical cord sera. Eur. J. Clin. Nutr. 53:486-494.

Leotsinidis, M., A. Alexopoulos, and E. Kostopoulou-Farri. 2005. Toxic and essential trace elements in human milk from Greek lactating women: Association with dietary habits and other factors. Chemosphere 61:238-247.

Lonnerdal, B. 2007. Trace element transport in the mammary gland. Annu. Rev. Nutr. 27:165-177.

Martini, M., I. Altomonte, F. Salari, and A. Caroli. 2014. Short communication: Monitoring nutritional quality of Amiata donkey milk: Effects of lactation and productive season. J. Dairy Sci. 97:6819-6822.

Nielsen, F. H. 1998. Ultratrace elements in nutrition: Current knowledge and speculation. J. Trace Elem. Exp. Med. 11:251-274.

NRC. 2005. Mineral Tolerance of Animals. 2nd rev. ed. Natl. Acad. Press, Washington, DC.

Patra, R. C., D. Swarup, P. Kumar, D. Nandi, R. Naresh, and S. L. Ali. 2008. Milk trace elements in lactating cows environmentally exposed to higher level of lead and cadmium around different industrial units. Sci. Total Environ. 404:36-43.

Potorti, A. G., G. Di Bella, V. Lo Turco, R. Rando, and G. Dugo. 2013. Non-toxic and potentially toxic elements in Italian donkey milk by ICP-MS and multivariate analysis. J. Food Compos. Anal. 31:161-172.

Rahimi, E. 2013. Lead and cadmium concentrations in goat, cow, sheep, and buffalo milks from different regions of Iran. Food Chem. 136:389-391.

Rey-Crespo, F., M. Miranda, and M. Lopez-Alonso. 2013. Essential trace and toxic element concentrations in organic and conventional milk in NW Spain. Food Chem. Toxicol. 55:513-518.

Rieker, J. M., S. R. Cooper, D. R. Topliff, D. W. Freeman, and R. G. Teeter. 2000. Copper balance in mature geldings fed supplemental molybdenum. J. Equine Vet. Sci. 20:522-525.

Rossipal, E., and M. Krachler. 1998. Pattern of trace elements in human milk during the course of lactation. Nutr. Res. 18:11-24.

Salimei, E. 2011. Animals that produce dairy foods-Donkey. Pages 365-373 in Encyclopedia of Dairy Sciences. Vol. I. 2nd ed. J. W. Fuquay, P. F. Fox, and P. L. H. McSweeney, ed. Academic Press, San Diego, USA.

Salimei, E., and F. Fantuz. 2013. Horse and donkey milk. Pages 594613 in Milk and Dairy Product in Human Nutrition: Production, Composition and Health. Y. W. Park and G. F. W. Haenlein, ed. John Wiley \& Sons, Oxford, UK.

Salimei, E., F. Fantuz, R. Coppola, B. Chiofalo, P. Polidori, and G. Varisco. 2004. Composition and characteristics of ass's milk. Anim. Res. 53:67-78.

Shennan, D. B., and M. Peaker. 2000. Transport of milk constituents by the mammary gland. Physiol. Rev. 80:925-951.

Suttle, N. F. 2010. The Mineral Nutrition of Livestock. 4th ed. CAB International, Wallingford, UK

Swarup, D., R. C. Patra, R. Naresh, P. Kumar, and P. Shekhar. 2005. Blood lead levels in lactating cows reared around polluted localities; transfer of lead into milk. Sci. Total Environ. 349:67-71.

Trancoso, I., L. B. Roseiro, A. P. L. Martins, and M. A. Trancoso. 2009. Validation and quality assurance applied to goat milk chemical composition: Minerals and trace elements measurements. Dairy Sci. Technol. 89:241-256.

Van Paemel, M., N. Dierick, G. Janssens, V. Fievez, and S. De Smet. 2010. Selected trace and ultratrace elements: Biological role, content in feed and requirements in animal nutrition-Elements for risk assessment. EFSA-Publications Connexes-Technical Report. EFSA-Q-2008-04990. Accessed Nov. 28, 2014. http://www.efsa. europa.eu/en/scdocs/doc/68e.pdf. 